\title{
Strategies of Knowledge Sharing in Farms Keeping Conservative Breed Livestock
}

\author{
Marta DOMAGALSKA-GREDYS \\ Agriculture University of Kraków, Kraków, Poland \\ rrdomagaecyf-kr.edu.pl
}

\begin{abstract}
The purpose of the study was to classify farms maintaining conservative breed livestock in terms of strategies of knowledge sharing with institutions. Data from 145 farms from south-eastern Poland was collected with a questionnaire in 2017. The strategies were determined on the basis of an IPA analysis.

The results show that Polish farmers implement livestock biodiversity protection programmes and create most numerous relationships with industry associations and advisory institutions. The subject of exchange in such relationships is knowledge and the largest quality gap is that of the farms following the concentration strategy (high importance and low intensity). Polish farmers implement the livestock species biodiversity protection programme creating most numerous relationships with industry organisations and advisory institutions. The object of sharing in these relationships is knowledge which indicates the existence of a continuous need to educate and adjust the training scope by institutions supporting agriculture. The role of institutions in supporting the biodiversity development processes is constantly increasing.
\end{abstract}

Keywords: IPA Importance Performance Analyse, Breeders, Knowledge Exchange.

\section{Introduction}

The Agricultural sector strongly needs to create, share and disseminate up-to-date and appropriate knowledge and information [7]. Recently, the concept of information sharing has attracted the attention of scholars, the most recent work was on the effect of information and knowledge sharing on performance [10]. Various scholars [4] argue that there are many factors enhancing value chain performance in addition to information sharing including trust and interaction. Trust depends to a large extent on information sharing and interaction.

Since the launch* (2013) of the subsidies for the livestock conservative breed protection programme in Poland no major specialised platform for knowledge and

\footnotetext{
* Regulation of the Minister of Agriculture and Rural Development of March 13, 2013, item 361 on the specific conditions and manner of subsidization within the framework of the "Agriculturalenvironmental programme" covered by the Rural Areas Development Programme for the years
} 
information sharing has emerged. Whereas Poland's public policy ${ }^{\dagger}$ is aimed at solving public problems related to economic development, social and environmental issues, there are still no effective solutions due to the delayed executive acts and their funding [12]. The efficiency of investments and innovation implementation in the scope of brokerage services (knowledge and information sharing) for breeders of livestock conservative breeds is still insufficient.

The breeders are left with conventional information channels which suggests that they typically work based on their own experience and experts' technical guidelines to determine which species are to be bred, for what products, how to associate with other producers and create economic networks. A large part of the knowledge base in in the experts' minds while individual breeders own it as concealed knowledge. There is a problem of a large amount of silent knowledge consisting in the fact that it is of a general nature, not species-specific (cattle, pigs, sheep, etc.). This is particularly important in a situation in which breeders are poorly organised. Also, no programme has been created that would support the organisation of this specific group of breeders implementing the biodiversity programme. The nature of breeding and the Polish regulations regarding food processing restrict the possibilities of marketing farm produce. Taking into account that animals are bred by small farms, their production scale and the ability to meet the quality requirements are limited in the light of strong competition on the part of breeders of traditional breeds and commercial network organisations. It is essential for the breeders of conservative breeds to cooperate in order to increase their development opportunities and change the existing approach. The breeders do not have full knowledge of the benefits the cooperation in groups brings, they are distrustful, and they do not take advantage of the opportunity to enter niche markets. In Poland, the consumers' interest in high-quality, certified food is increasing. Such production requires the breeders to expand their knowledge, e.g. by actively exchanging it with institutions such as Agricultural advisory centres, research institutes, industry associations.

Knowledge sharing traditionally by various courses should be combined with knowledge sharing via specialised websites. It follows from the research [6] that technical trainings for farmers are needed in the field of use of communication and information technologies that increase the transfer of information. Quick and global access to information and knowledge e.g. via ICT implies changes in the process of innovation which is based on recombination of the existing knowledge to increase the possibility of creating something new [1].

Small and medium companies (like farms) rarely have all the knowledge necessary for their effective management; in addition, the scope of essential knowledge changes with growth of the company [11]. Business consulting is characterised by diversity in relations to the content of services provided to compagnies of various sizes and the different stages development [8]. Owners like farmers are more likely to use other types of advisers instead of business consulting firm and professional consultants. They tend

2007-2013. Package 7 of the said regulation refers to the conservation of endangered genetic resources in agriculture.

A network for innovation and in rural areas was created in Poland (SIR), within the scope of the European Innovation Partnership. 
to use business relations (friends, family) that do not perform advisory functions, such as accountants, suppliers, bank staff [3].

\section{Methodology}

The purpose of research was to classify the farms with conservative breed livestock (cattle, sheep and pigs) in terms of how they exchange knowledge with institutions. Data from 145 farms in south-eastern Poland was collected with a direct interview questionnaire in 2017.

The study of the knowledge exchange was based on the assumption that it constitutes an act of providing of a specific service in which the farms are customers and the institutions are service providers. According to the network theory, a relationship occurs where there is common goal and exchange between entities occurs. The scope of exchange was narrowed down to knowledge due to the insignificance of other forms of exchange (material resources and skills). The knowledge of farmers keeping conservative breed livestock constituted, in turn, a guideline for estimation of educational and training needs ( $\rightarrow$ context of evaluation of social capital).

Assuming that the knowledge sharing relationships are services and that the causes determining the intensity and importance of knowledge sharing are complex, the IPA method used in the research of this kind was applied [9]. It allowed the relationship quality to be evaluated and the strategies of knowledge exchange to be classified. The extent of the gap between the evaluation of knowledge sharing intensity and their importance allows the "remedial" actions, such as: trainings, education, stimulation of relationship (meetings, trips) to be determined.

\section{Results}

The studied farms created numerous relationships. Apart from customers and suppliers, economic relationships included: industry, advisory, scientific and state administration organizations (UM, UG, ARiMR, ARR) who the studied farms cooperated with. The results provided in this paper refer to the entirety of the relationships formed by farms, including all institutional entities.

The concept of the IPA is based on the combination of four fields with results evaluation of intensity and the importance of given traits (any number of traits subject to evaluation). For the research presented in the paper, the importance and intensity were evaluated for the exchange of knowledge between farms with conservative breeds and the institutions they interact with. The score could range from 1 to 5 . As a result of such arrangement of scores, average relationship scores were obtained based on knowledge exchange in four fields in the context of their importance and intensity (see Fig. 2). Each field means a different arrangement of scores (the proportion of importance to intensity). If the evaluation of intensity and importance was high (from 2.5 to 5), the relationship was in the field (f) of maintaining good relationships. In turn, if the importance and evaluation scores were low (from 0 to 2.5) the relationship was in the field of (d) trivialities. The analysis allowed the evaluations of importance and 
intensity which define the quality gap to be compared. The higher the difference, the bigger the gap.

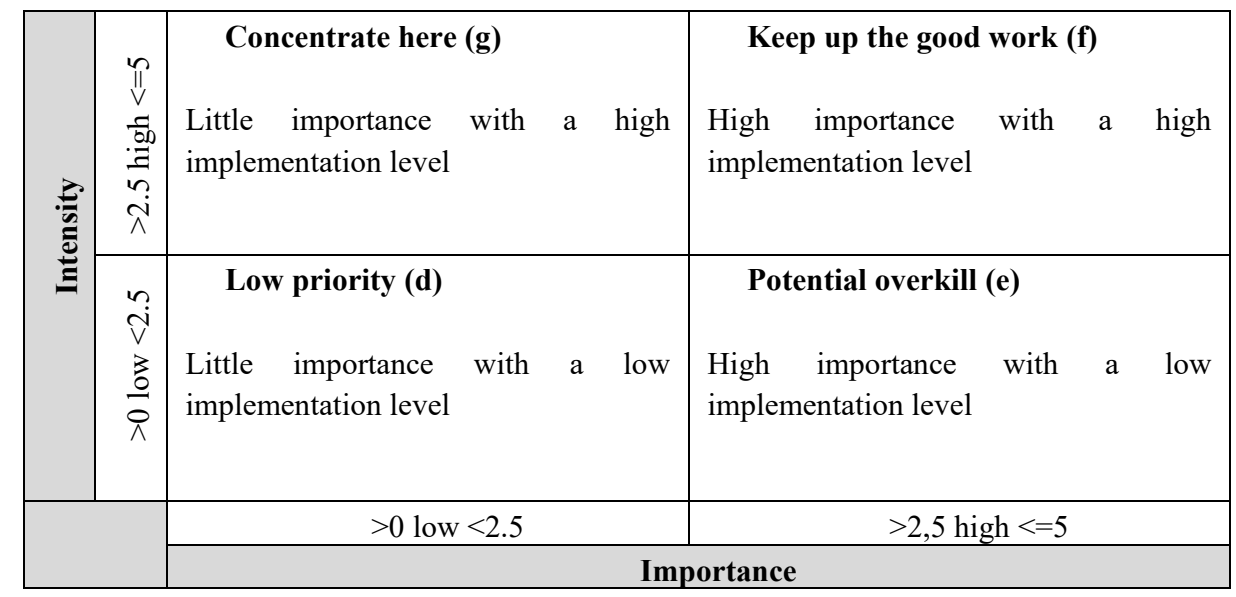

Fig. 1. Drawing of IPA analysis model.

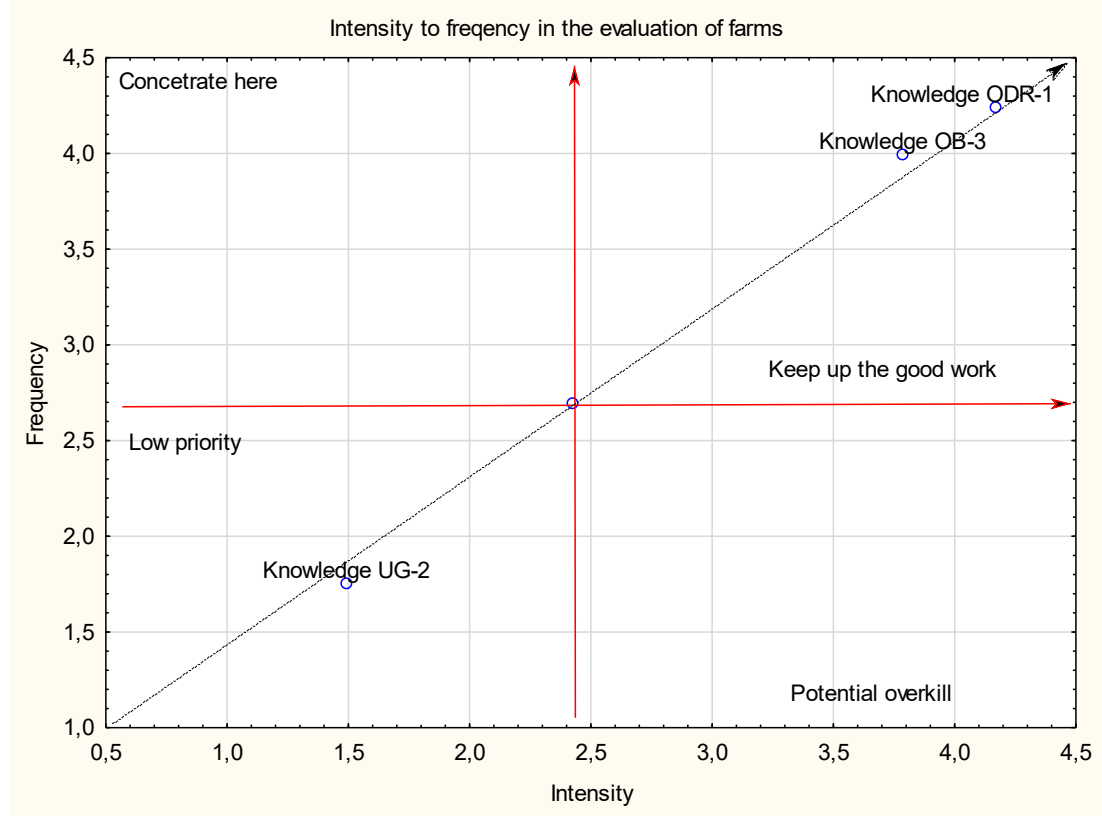

Fig. 2. Importance versus frequency of knowledge sharing between farms and institutions (Agricultural advisory centres (ODR), Industry organisations (OB), Municipalities $(U G)=$ local government institutions (UG)). 
In the group of studied farms, the exchange of knowledge was of the highest importance for farms cooperating with industry organisations and agricultural advisory centres. These relationships were in the field of "keep up the good work" strategy. Conversely, knowledge sharing with municipalities was of little importance (see Fig. 2).

The most numerous form of relationship (73.10\%) were $d$ (field of trivialities) with a low importance and low intensity. The least numerous $(2.76 \%)$ were g (excessive care) with little importance and a high intensity. The f relationships turned out to be popular (field of maintaining good position) (12.41\%) with a high intensity and high importance which were handled according to the strategy typical for the field of trivialities (low importance and frequency of sharing; see: Table 1).

Table 1. Average scores of intensity and importance of knowledge sharing between farms and institutions in IPA fields.

\begin{tabular}{lccccc}
\hline & $\begin{array}{c}\text { Intensity } \\
\text { Fields of IPA }\end{array}$ & $\begin{array}{c}\text { Importance } \\
(\mathrm{N})\end{array}$ & $\begin{array}{c}\text { Gap } \\
(\mathrm{M}-\mathrm{N})\end{array}$ & $\begin{array}{c}\text { Number } \\
\text { of farms }\end{array}$ & $\begin{array}{c}\text { IPA field } \\
\text { per cent }\end{array}$ \\
\hline d. Trivialities & 1.27 & 1.39 & 0.12 & 106.00 & $73.10 \%$ \\
e. Concentration & 2.02 & 2.90 & 0.88 & 17.00 & $11.72 \%$ \\
f. Maintaining a good position & 2.80 & 3.03 & 0.24 & 18.00 & $12.41 \%$ \\
g. Excessive care & 2.34 & 1.97 & -0.38 & 4.00 & $2.76 \%$ \\
$\quad$ Average score & 1.58 & 1.79 & 0.21 & 145.00 & $100.00 \%$ \\
\hline
\end{tabular}

A large gap in the field of concentration (e) means the necessity of committing training efforts in order to understand the development perspectives for farms due to knowledge sharing (Table 1).

The largest gap in the evaluation for field e (0.88) means the importance is higher than the intensity (relationships are not frequent but are important). In turn, frequent relationships with low importance occurred in field $g$ (field of excessive care, see Table 1).

\section{Discussion}

Surely for the development of relationships between farmers, it must be determined what kind of knowledge they need (technological, market-related, coaching). There are premises for believing that certain variables define IPA strategies better (such as economic, relationship strength over time, $\%$ of produce procurement).

The results indicate that the Polish farmers implement the livestock species biodiversity protection programme creating most numerous relationships with industry organisations and advisory institutions. The object of sharing in these relationships is knowledge which indicates the existence of a continuous need to educate and adjust the training scope by institutions supporting agriculture. The role of institutions in supporting the biodiversity development processes is constantly increasing. The market problems faced by farms keeping conservative breeds require institutional support. 
The largest quality gap was observed in the farms following the strategy of concentration (high importance and low intensity). The weakest relationships (low importance and low intensity - strategy of trivialities) were formed by a majority of farms $(73.1 \%)$ with the lowest share of production under advance procurement contracts and low income.

The group of farms $(12.41 \%)$ with the highest evaluation of relationships (high importance and high intensity - strategy of maintaining a good position) included entities with highest share of production under advance procurement contracts and high income.

\section{Conclusions}

In the context of biodiversity development, the farms following the strategy of maintaining a good position should be especially valued, while the farms following the strategy of trivialities should be monitored. The entities which do not value knowledge and sharing it, are at risk of being forced out of the market. The lack of knowledge restricts their access to advance procurement contracts and makes them miss the opportunity for profit (they do not know what, when and where they are missing).

Acknowledgements. The publication regards the BIOSTRATEG2/297267/14/NCBR/ /2016 project, funded by the National Centre for Research and Development under the Biostrateg programme entitled 'Directions for the Use and Conservation of Livestock Genetic Resources in the Conditions of Sustainable Development.

\section{References}

1. Arvanitidis, P. A., Petrakos, G.: Defining knowledge-driven economic dynamism in the world economy: A methodological perspective. In: Nijkamp P., Siedschlag I. (eds.) Innovation, growth and competitiveness: Dynamic regions in the knowledge-based world economy, pp. 15-39, Springer-Verlag, Berlin (2011).

2. Castells, M.: Społeczeństwo sieci. 1st edn. PWN, Warsaw (2013).

3. Głodek, P.: Zaufanie a źródła doradztwa małej firmy. 1st edn. Wydawnictwo Uniwersytetu Ekonomicznego we Wrocławiu, Wroclaw (2017).

4. Grootaert, C., Bastelaer, T.: The role of social capital in development: An empirical assessment. 1st edn. Cambridge University Press, Cambridge (2002).

5. Hopp, W.: Trust, Trustworthiness, and Information Sharing in Supply Chains Bridging China and the United States. Journal Management Science, 60(10), 2435-2460 (2014).

6. Howland, F., Muñoz, L.A., Staiger-Rivas, S., Cock, J., Alvarez, S.: Data sharing and use of ICTs in agriculture: working with small farmer groups in Colombia. Knowledge Management for Development Journal, 11(2), 44-63 (2015).

7. Lotfi, Z., Mukhtar, M., Sahran, S., Zadeh, A. T.: Information sharing in supply chain management. Procedia Technology, 11, 298-304 (2013). DOI: 10.1016/j.protcy.2013.12.194. 
8. Mole, K.F., Baldock, R., North, D.: Who takes advice? Firm size they should competence, concerns and informality in a contingency approach. ECR Research Paper 9, 9, 1-38 (2013).

9. Meng S., W., Nishimoto, H., Philip, G.: The Use of Importance-Performance Analysis (IPA) in Evaluating Japan's E-government Services. Journal of Theoretical and Applied Electronic Commerce Research, 6(2), 17-30 (2011).

10. Rashed, C. A. A., Azeem, A., Halim, A.: Effect of information and knowledge sharing on supply chain performance: A survey-based approach. Journal of Operations and Supply Chain Management, 3(2), 61-77 (2010).

11. Stawasz, E.: Rola doradztwa gospodarczego w zarządzaniu mikroprzedsiębiorstwamiwybrane oddziaływania i determinant. Prace Naukowe Uniwersytetu Ekonomicznego we Wrocławiu, $\quad 419, \quad 228-236, \quad$ (2016). 10.15611/pn.2016.419.20.

12. Wiatrak, A.: The essence and conditions of brokerage services in the implementation of innovation in agribusiness. Scientific Annals of the Association of Agricultural Economists and Agribusiness, XX(4), 201-204 (2018). DOI: 10.5604/01.3001.0012.3062. 